Pak. J. Agri., Agril. Engg., Vet. Sci., 2020, 36 (1): 34-41

ISSN: 1023-1072 (Print), ISSN: 2663-7863 (Online)

https://doi.org/10.47432/pjaaevs.2020.36.1.6

\title{
IMPACT OF GREEN REVOLUTION POLICY ON RURAL POVERTY IN PAKISTAN: A CASE STUDY OF DISTRICT SHAHEED BENAZIRABAD SINDH
}

\author{
A. A. Joyo ${ }^{1}$, G. A. Jariko ${ }^{1}$ and Z. H. Channa ${ }^{2}$ \\ ${ }^{1}$ Sindh Develepment Study Centre, University of Sindh, Jamshoro, Pakistan \\ ${ }^{2}$ Department of Economics, Shaheed Benazir Bhutto University, \\ Shaheed Benazirabad, Pakistan
}

\begin{abstract}
This paper determines the relationship between Green Revolution policy and rural poverty in Pakistan and also to findout the poverty status in the study area. The data collection was based on primary and secondary sources of information. The primary data was collected from 405 respondents living in the district Shaheed Benazirabad, through field survey whereas secondary data was collected from various published articles, reports, periodicals, etc. The data were analyzed with the help of Statistical Package developed for Social Sciences (SPSS-20). The key respondents were divided into three categories of farmers i.e. 325 respondents were small size land owner farmers, 42 respondents were medium size land owners and 38 were large size land owners. These all farmers had total 4044 acres. This study mainly focused on wheat and cotton crops cultivated by all farmers in the district. The secondary data covers per hectare yield of food and cash crops grown in the country that increased the income of farmers and reduced poverty. The average family size included in the study was six members. The poverty line was measured by the method Cost of Basic Needs (CBN) introduced by the Planning Commission of Pakistan; that is Rs.3030/- monthly expenditure of each family member. The results obtained from the study further indicated that the average monthly expenditure of small farmers was Rs.18,989/- and their income was Rs.17,439/- (Rs.17,439 - Rs.18,989 -1550). The number of small farmers was 325 , who were below the poverty line particularly in winter season (wheat crop), which is the second crop sowing season in Pakistan.
\end{abstract}

Keywords: agriculture, cost of basic needs, expenditure, green revolution, hectare, income, rural poverty

\section{INTRODUCTION}

The agriculture sector plays a vital role in Pakistan's economy. Pakistan depends on agriculture sector since its inception, it has geographical area of 79.61 million hectares. About 27 percent area of Pakistan is currently under cultivation; from this 80 percent area is irrigated through canals. In this regard, Pakistan has highest proportion of canal irrigated cropped area in the world. The cultivated waste land offering good possibilities of crop production amount to 8.9 million hectares. Growth in cropped area is very impressive from 11.6 million hectares in 2015/16 (PES, 2016). Pakistan possesses rich and vast natural resources, covering various ecological and climatic zones. Hence, the country has great

*Corresponding author: aajoy014@yahoo.com potential for producing all kinds of food commodities. The importance of agriculture to the economy has been observed in three ways: first, providing food to population and raw material to the domestic industry; second it is a source of foreign exchange earnings: and third, it provides a market for industrial goods. This sector contributes about 18.9 percent to Gross Domestic Production (GDP) and employed labor force 42.3 percent (PES, 2018). The contribution of the agriculture sector to the GDP has declined from 53.2 percent in 1953 to 18.9 percent in 2017/18 (PES, 2018); because of industry and service sectors in Pakistan.

After independence of Pakistan, the growth rate of agricultural sector was 1.3 percent during 1947/48 to 1958-59 (Zaidi, 2015). Therefore, need was felt to introduce new technologies in this sector. The main purpose was to enhance per acre yield of farmers and improve their 
socio- economic conditions. Thus Green Revolution was launched in 1966 (Zaidi, 2015). It was initiated by the public sector to enhance output of food and cash crops. According to Viqar and Amjad (1984) the technologies focused on: (a) irrigation management (b) inclusion of high yielding varieties (c) fertilizer application (d) pesticides.

The irrigation system of Pakistan is the basic component for the development of agriculture sector. The availability of water rose from 64 MAF to 133.4 MAF during the period 1966 to 2018 (GoP, 2018). The seed of high yielding varieties was imported from Mexico (wheat) during 1960s (Zaidi, 2015). The use of these seeds rose from 22.54 (000 tons) to 476.61 (000) tons during the period 1971-72 to 2017-18. The high yielding varieties required chemical fertilizer for increasing yield of farms. Rice consumption grew from $112(000 \mathrm{~N}$. tons) to 4763 (000 N. tons) (GoP, 2018-19). However, pests and plant diseases severely destroyed crops and the losses were estimated about 20 to 30 percent (Mahmood, 2011). Therefore, it is necessary to protect the plants by applying pesticides. The consumption of pesticides increased from 14,499 million tons to 26,480 million tons during the period 1986 to 2018 (GoP, 2018). A sample of 32 African countries was prepared during the period 1990 to 2011 and it was proved that by applying new technological innovations in these countries, agricultural productivity increased that reduced poverty by 32 percent (Dhrifi Abedulhfidh, 2014). In China, 1.7 percent, in Bangladesh 24.3 percent, in India 21.9 percent and in Srilanka 4.1 percent population is living below the poverty line.

In beginning Pakistan's eighty percent population was engaged in agriculture related activities and applied traditional methods for cultivation. Therefore, yield per acre was low that significantly affected their income. While, the agriculture sector remained stagnant in position from 1947 to 1958 due to administrative issues faced by the newly born country. The average growth rate of agriculture sector was 1.3 percent against population growth rate 2.6 percent (Naseem, 1981). In Pakistan during 1958 to 1968 Asian Development Bank set up a loan facility for farmers to increase agricultural output. Meanwhile, the Green Revolution policy was introduced in 1966 to enhance per hectare yield. Although, the landlords got benefits from the bank loans; the small farmers were totally neglected. The small farmers had low income so they could not afford to intake 2100 calories per day. Poverty in rural areas of Pakistan during 1960s was observed 42.28 percent (Bhutto and Bazmi, 2007) and 25 percent urban housholds and 37 perecnt rural households were below the poverty line (Idrees, 2017). The poverty was found to be higher in rural area (48.44\%) than in urban area $(26.78 \%)$.

In 1970s poverty had declined (Malik, 1988; Ahmed and Ludlow, 1989; Ercelawn, 1990). The large number of industrial units and banks were nationalized. More poverty during the 1950 s was observed due to administrative problems faced by newly independent country, the high trends of poverty were observed during 1990s due to political instability, high expenditure on nuclear testing and fiscal deficit (Asghar et al., 2012). The land reforms 1972 and 1977 were launched and resumed land was distributed among landless farmers. According to Banking Reform 1972 all banks were allowed to provide loan facility to all farmers. Manpower from rural and urban areas was exported to Middle East countries. Infrastructure of rural areas was developed. It facilitated farmers to sale their produce in urban markets at reasonable price. Such steps grew real GDP and the growth rate was achieved more than six percent per annum. The introduction of economic and welfare measures had achieved a rapid increase in foreign exchange earnings into economy (Amjad and Kamal, 1997). Poverty reduced by providing microfinance to the poor people in the district Faisalabad during the period 2014, before taking the loan poverty was high and after taking the loan it was reduced (Imtiaz et al., 2014). Growth of agriculture sector during 1960s was found to be high and it was also observed that poverty (40 percent) which was also at high side in the country; mostly in rural areas. It was reduced after 1970 till 1987/88 after this period trend of poverty reversed, during the period $2001 / 2002$, it was estimated from 32 percent to 36 percent (Shirazi and Khan, 2009).

Thus poverty trends decreased during 1980 to 17.32 percent at national level and rural poverty declined to 18.32 percent in the year 1987. The trends of poverty started to increase during 1990s. The poverty at national level was 22.11 percent which increased to 55.2 percent as whole and the rural poverty rose from 23.59 percent to 57.4 percent during 1990-91 to 200506 (ESP, 2007). The main reason was IMF Structural Adjustment Program to reduce the current account deficit, to decrease inflation, increase growth rate of economy and cut the 
fiscal deficit (Zaidi, 2015). These aims were not achieved, but it enhanced poverty at national and rural level. Later on further measures were adopted to reduce poverty that declined to 24.3 percent at national level, 12.5 urban and 30.7 rural areas of Pakistan (PES, 2018).

\section{MATERIALS AND METHODS}

\section{Study area}

It was based on primary data limited to district Shaheed Benazirabad (SBA) Sindh province of Pakistan. The data was collected from four talukas viz., Daur, Nawabshah, Sakrand and Kazi Ahmed through field survey and face to face interview with 405 farmers.

\section{Approach of data collection}

The primary data was collected from four talukas of district Shaheed Benazirabad, 405 farmers were chosen for conducting interview from 53 villages of 22 dehs/wards. The key respondents were divided into three categories such as (a) 325 small farmers, (b) 42 medium farmers and (c) 38 large farmers of the district.The secondary data was collected from published literature including, national and international journals, periodicals, annual reports of government such as Economic Survey of Pakistan and Agricultural Statistics of Pakistan.

\section{Statistical method}

The total cost, total production total income and average income per acre of wheat and cotton productivity were analyzed with the help of Statistical Package developed for Social Sciences (SPSS-20). The Descriptive Statistics was also applied for frequency analysis and to compare means. The mean, minimum, maximum, and sum were also determined.

\section{Sample size formula}

Total sample size 405 was selected from four talukas of district Shaheed Benzirabad, its population is 1,612,847 (GoP, 2018). Out of 405 respondents 85 were selected from Daur, 97 from Nawabshah, 117 from Sakrand and 106 were chosen from Kazi Ahmed taluka.

Following formula of Taro Yamane (1967) was used for collection of sample size:

$n=\frac{N}{1+N(e)^{2}}$

Where:

$\mathrm{N}=$ population $\mathrm{n}=$ sample size

$\mathrm{e}=$ level of precision

A 95\% confidence level and $P=0.5$ are assumed

$\mathrm{n}=\frac{1612847}{1+1612847(0.5)^{2}}$

$\mathrm{n}=\frac{1612847}{1+1612847 \times 0.0025}$

$\mathrm{n}=\frac{1612847}{1+4032.1175}$

$\mathrm{n}=\frac{1612847}{4033.1175}$

$\mathrm{n}=399.9$

Say: 400

However, the researcher has chosen 405 sample size for research study purpose.

\section{RESULTS AND DISCUSSION \\ Land holding}

The land holding pattern adopted by the farmers given in Table 1, indicate the categories of farmers and land in acres. The farmers were generally found to cultivate their land and earn incomes seasonally, i.e. Kharif and Rabi seasons.

Table 1. Land holding pattern of the key respondents (farmers) in the study area

\begin{tabular}{|l|l|l|l|}
\hline $\begin{array}{l}\text { Land holding } \\
\text { pattern of the key } \\
\text { respondents }\end{array}$ & $\begin{array}{l}\text { No of key } \\
\text { respondents }\end{array}$ & $\begin{array}{l}\text { Total land } \\
\text { (acres) }\end{array}$ & $\%$ \\
\hline $\begin{array}{l}\text { Small farmers } \\
(1-12 \text { acres) }\end{array}$ & 325 & 1410 & 35 \\
\hline $\begin{array}{l}\text { Medium farmers } \\
(13-25 \text { acres })\end{array}$ & 42 & 804 & 20 \\
\hline $\begin{array}{l}\text { Large farmers } \\
(26-50 \text { and above } \\
\text { acres) }\end{array}$ & 38 & 1830 & 45 \\
\hline Total & 405 & 4044 & 100 \\
\hline
\end{tabular}

Source: Study Survey 2017-18

Table 1 shows the respondents (farmers) categories in the study area. The large number of farmers was 325 having 1410 acres which stood 35 percent, whereas medium farmers had 804 acres that covers about 20 percent and large farmers owned 1830 acres which stood 45 percent of the total land in the study area. 
Pak. J. Agri., Agril. Engg., Vet. Sci., 2020, 36 (1)

Table 2. Analysis of cultivated and un-cultivated area during summer and winter seasons

\begin{tabular}{|c|c|c|c|c|c|c|c|c|c|c|c|c|}
\hline \multirow[t]{2}{*}{$\begin{array}{l}\text { Cateogory } \\
\text { of farmers }\end{array}$} & \multicolumn{8}{|c|}{ Cultivated and un-cultivated area of summer crops } & \multicolumn{4}{|c|}{$\begin{array}{l}\text { Cultivated and un-cultivated area of } \\
\text { winter crop }\end{array}$} \\
\hline & $\begin{array}{l}\text { Number } \\
\text { of } \\
\text { Farmers }\end{array}$ & $\begin{array}{l}\text { Total } \\
\text { land } \\
\text { (acres) }\end{array}$ & $\begin{array}{l}\text { Cultivated } \\
\text { land } \\
\text { (acres) } \\
\text { cotton }\end{array}$ & $\%$ & $\begin{array}{l}\text { cultivated } \\
\text { land } \\
\text { (acres) } \\
\text { sugarcane }\end{array}$ & $\%$ & \begin{tabular}{|l} 
Un- \\
cultivated \\
land \\
(acres)
\end{tabular} & $\%$ & $\begin{array}{l}\text { Cultivated } \\
\text { land wheat } \\
\text { (acres) }\end{array}$ & $\%$ & $\begin{array}{l}\text { Un- } \\
\text { cultivated } \\
\text { land } \\
\text { (acres) }\end{array}$ & $\%$ \\
\hline $\begin{array}{l}\text { Small } \\
\text { farmers } \\
1-12 \text { acres }\end{array}$ & 325 & 1410 & 1301.5 & 32.0 & 58 & 1.00 & 50.5 & 1.20 & 1330 & 33.0 & 22 & 0.54 \\
\hline $\begin{array}{l}\text { Medium } \\
\text { farmers } \\
13-25 \text { acres }\end{array}$ & 42 & 804 & 621 & 15.3 & 122 & 3.00 & 61 & 1.50 & 664 & 16.0 & 18 & 0.44 \\
\hline $\begin{array}{l}\text { Large } \\
\text { farmers } \\
26-50 \text { and } \\
\text { above } \\
\text { acres }\end{array}$ & 38 & 1830 & 1126 & 28.0 & 389 & 10.00 & 315 & 8.00 & 1212 & 30.0 & 230 & 6.0 \\
\hline Total & 405 & 4044 & 3048.5 & 75.30 & 569 & 14.00 & 426.5 & \begin{tabular}{|l}
10.70 \\
\end{tabular} & 3206 & 79.0 & 270 & 7.0 \\
\hline
\end{tabular}

Table 3. Average size of farms in cultivated area of wheat and cotton production

\begin{tabular}{|c|c|c|c|c|c|c|}
\hline \multirow{2}{*}{$\begin{array}{l}\text { Category of } \\
\text { farmers }\end{array}$} & \multirow{2}{*}{$\begin{array}{l}\text { Number of } \\
\text { Farmers }\end{array}$} & \multirow{2}{*}{$\begin{array}{l}\text { Total land } \\
\text { ( acres) }\end{array}$} & \multicolumn{4}{|c|}{ Cultivated land (acres) } \\
\hline & & & Cotton & Average size & Wheat & Average size \\
\hline $\begin{array}{l}\text { Small farmers } \\
1-12 \text { acres }\end{array}$ & 325 & 1410 & 1301.5 & 4.0 & 1330 & 04.0 \\
\hline $\begin{array}{l}\text { Medium farmers } \\
13-25 \text { acres }\end{array}$ & 42 & 804 & 621.0 & 15.0 & 664 & 16.0 \\
\hline $\begin{array}{l}\text { Large farmers } \\
26-50 \text { and } \\
\text { above acres }\end{array}$ & 38 & 1830 & 1126.0 & 30.0 & 1212 & 32.0 \\
\hline Total & 405 & 4044 & 3048.5 & - & 3206 & - \\
\hline
\end{tabular}

Source: $\quad$ Study Survey 2017-18

Table 4. Total average cost and average net income of cotton production per acre

\begin{tabular}{|c|c|c|c|c|c|c|}
\hline $\begin{array}{lr}\text { Category } & \text { and } \\
\text { Number } & \text { of } \\
\text { Farmers } & \end{array}$ & --- & $\begin{array}{l}\text { Total Cost } \\
\text { (in Rs) }\end{array}$ & $\begin{array}{l}\text { Total Product } \\
\text { (in maunds) }\end{array}$ & $\begin{array}{l}\text { Rate per maund } \\
\text { (in Rs) }\end{array}$ & $\begin{array}{l}\text { Total Income (in } \\
\text { Rs) }\end{array}$ & $\begin{array}{l}\text { Net Income (in } \\
\text { Rs) }\end{array}$ \\
\hline \multirow{4}{*}{$\begin{array}{lr}\text { Small } & \text { farmers } \\
1-12 & \text { acres } \\
\text { (cases } & 325 \text { ) }\end{array}$} & Average & 26895.08 & 24.66 & 3277.85 & 80816.31 & 53921.23 \\
\hline & Minimum & 23600 & 22 & 3100 & 73600 & 43000 \\
\hline & Maximum & 30600 & 27 & 3500 & 94500 & 64000 \\
\hline & Sum & 8740900 & 8015 & 1065300 & 26265300 & 17524400 \\
\hline
\end{tabular}

\begin{tabular}{|l|l|l|l|l|l|l|}
\hline $\begin{array}{l}\text { Category and } \begin{array}{l}\text { Number of } \\
\text { Farmers }\end{array} \\
\text { Medium farmers }\end{array}$ & $\begin{array}{l}\text { Total Cost } \\
\text { (in Rs) }\end{array}$ & $\begin{array}{l}\text { Total } \\
\text { Production } \\
\text { (in maunds) }\end{array}$ & $\begin{array}{l}\text { Rate per maund } \\
\text { (in Rs) }\end{array}$ & $\begin{array}{l}\text { Total Income (in } \\
\text { Rs) }\end{array}$ & $\begin{array}{l}\text { Net Income (in } \\
\text { Rs) }\end{array}$ \\
\cline { 2 - 6 } (cases 42) & Average & 27878.57 & 25.12 & 3302.38 & 83038.10 \\
\cline { 2 - 7 } & Maximum & 23600 & 23 & 2100 & 55159.52 \\
\cline { 2 - 7 } & Sum & 30500 & 27 & 3500 & 94500 & 3400 \\
\hline
\end{tabular}

\begin{tabular}{|c|c|c|c|c|c|c|}
\hline $\begin{array}{l}\text { Category and } \\
\text { Number of } \\
\text { Farmers }\end{array}$ & --- & $\begin{array}{l}\text { Total Cost } \\
\text { (in Rs) }\end{array}$ & $\begin{array}{l}\text { Total } \\
\text { Production } \\
\text { (in maunds) }\end{array}$ & $\begin{array}{l}\text { Rate per maund } \\
\text { (in Rs) }\end{array}$ & $\begin{array}{l}\text { Total Income (in } \\
\text { Rs) }\end{array}$ & $\begin{array}{l}\text { Net Income (in } \\
\text { Rs) }\end{array}$ \\
\hline \multirow{4}{*}{$\begin{array}{l}\text { Large farmers } \\
26-50 \quad \text { and } \\
\text { above } \\
\text { (cases 38) }\end{array}$} & Average & 30473.68 & 26.74 & 3473.68 & 92918.42 & 62444.74 \\
\hline & Minimum & 29500 & 24 & 3200 & 80000 & 50500 \\
\hline & Maximum & 30500 & 27 & 3500 & 94500 & 64000 \\
\hline & Sum & 1158000 & 1016 & 132000 & 3530900 & 2372900 \\
\hline
\end{tabular}

Source: Study Survey 2017-18

Table 2 illustrates the cultivated and uncultivated land by the 405 farmers in summer and winter seasons. About 3048.5 (75.30\%) acres were brought under cultivation of cotton; 569 acres (14.0\%) under sugarcane whereas un-cultivated land was 426.5 (10.70\%) acres in summer season out of 4044 acres. In winter season, the cultivated area was 3206 acres
(79.0\%) and un-cultivated area was about 270 acres $(7.0 \%)$ out of total 4044 acres. The uncultivated land was mainly due to the shortage of irrigation water.

\section{Average size of farm}

Table 3 describes the average size of farms remained under wheat and cotton production. 
The small farmers cultivated 1301.5 acres, the average farm size was 4.0 acres for both wheat and cotton crops; whereas, medium farmers cultivated 621 acres, the average size of farm was 15.0 and 16.0 acres in cotton and wheat crops, respectively. The large farmers had 1126 acres and 1212 acres land for cultivation with 30.0 acres average farm size in cotton production and 32.0 acres average size of farm in wheat production, respectively. All farmers cultivated 3048.5 acres land in summer season and 3206 acres in winter season in study area of the district.

The data given in the Table 4 illustrate the average net income of 325 small farmers they earned from cotton crop. Average size of farm land was 4 acres. The market rate was Rs.3277.85 per maund, minimum and maximum rates are mentioned in the same Table 4 . Total income Rs.80,816/- minus cost of cultivation per acre Rs.26,895/- they got net income of Rs.53,921/- per acre. Average production remained 24.66 maund per acre (minimum 22 and maximum 27 maunds per acre). Thus total net income of each farmer stood Rs.215,684/this amount was divided by six months, hence they received monthly average net income of Rs.35,947/- from cotton production.
Table 4 also indicates that about 42 medium farmers were inquired about their income which they achieved from cotton production. They had average yield per acre of cotton crop 15 maunds. The market rate was Rs.3302.38 per maund, this table also shows minimum and maximum rates. Their average net income stood Rs.55,160/- per acre , after deducting cultivation cost from total income. The average, minimum and maximum production per acre was also recorded. The total income of each farmer was Rs.827,400/- this amount was again divided by six months, hence they received average net income of Rs.137,900/- per month.

Table 4 also denotes the large farmers' income of cotton crop having 30 acres average farm size. The average market rate was Rs.3473.68 per maund, average, minimum and maximum production per acre is also shown in this table. The minimum and maximum rate was Rs.3200 and Rs.3500, respectively. Thus large farmers got average net income of Rs.62,445/per acre as a result of total income Rs.92, 918/-, minus average total cost of cultivation per acre Rs.30,474/-. The total income of each farmer was Rs.1,873,350/- this amount was divided by six months, hence they received average net income of Rs.312,225/- per month from cotton crop.

Table 5. Total average cost and average net income of wheat production per acre

\begin{tabular}{|c|c|c|c|c|c|c|}
\hline $\begin{array}{l}\text { Category and } \\
\text { Number of } \\
\text { Farmers }\end{array}$ & - & $\begin{array}{l}\text { Total cost } \\
\text { (in Rs) }\end{array}$ & $\begin{array}{l}\text { Total product } \\
\text { (in maunds) }\end{array}$ & $\begin{array}{l}\text { Rate per maund } \\
\text { (in Rs) }\end{array}$ & $\begin{array}{l}\text { Total income (in } \\
\text { Rs) }\end{array}$ & $\begin{array}{l}\text { Net income } \\
\text { (in Rs) }\end{array}$ \\
\hline \multirow{4}{*}{$\begin{array}{l}\text { Small farmers } \\
1-12 \text { acres } \\
\text { (cases } 325 \text { ) }\end{array}$} & Average & 24871.38 & 41.02 & 1244.62 & 51029.38 & 26158 \\
\hline & Minimum & 20850 & 36 & 1150 & 46000 & 20800 \\
\hline & Maximum & 29200 & 45 & 1300 & 58500 & 31600 \\
\hline & Sum & 8083200 & 13330 & 404500 & 16584550 & 8501350 \\
\hline $\begin{array}{l}\text { Category and } \\
\text { Number of } \\
\text { Farmers }\end{array}$ & - & $\begin{array}{l}\text { Total cost } \\
\text { (in Rs) }\end{array}$ & $\begin{array}{l}\text { Total product } \\
\text { (in acres) }\end{array}$ & $\begin{array}{l}\text { Rate per maund } \\
\text { (in Rs) }\end{array}$ & $\begin{array}{l}\text { Total income (in } \\
\text { Rs) }\end{array}$ & $\begin{array}{l}\text { Net income } \\
\text { (in Rs) }\end{array}$ \\
\hline \multirow{4}{*}{$\begin{array}{l}\text { Medium farmers } \\
13-25 \text { acres } \\
\text { (cases 42) }\end{array}$} & Average & 25688.10 & 41.31 & 1267.86 & 52370.24 & 26682.14 \\
\hline & Minimum & 21450 & 36 & 1150 & 46000 & 21950 \\
\hline & Maximum & 30300 & 45 & 1300 & 58500 & 31050 \\
\hline & Sum & 1078900 & 1735 & 53250 & 2199550 & 1120650 \\
\hline $\begin{array}{l}\text { Category and } \\
\text { Number of } \\
\text { Farmers }\end{array}$ & - & $\begin{array}{l}\text { Total cost } \\
\text { (in Rs) }\end{array}$ & $\begin{array}{l}\text { Total product } \\
\text { (in acres) }\end{array}$ & $\begin{array}{l}\text { Rate per maund } \\
\text { (in Rs) }\end{array}$ & $\begin{array}{l}\text { Total income (in } \\
\text { Rs) }\end{array}$ & $\begin{array}{l}\text { Net income (in } \\
\text { Rs) }\end{array}$ \\
\hline \multirow{4}{*}{$\begin{array}{l}\text { Large farmers } \\
26-50 \text { and } \\
\text { above } \\
\text { (cases } 38 \text { ) }\end{array}$} & Average & 29356.58 & 44.42 & 1293.42 & 57475 & 28118.42 \\
\hline & Minimum & 23700 & 39 & 1200 & 48750 & 22850 \\
\hline & Maximum & 30300 & 45 & 1300 & 58500 & 30300 \\
\hline & Sum & 1115550 & 49150 & 49150 & 2184050 & 1068500 \\
\hline
\end{tabular}

Source: Study Survey 2017-18

Table 6. Average monthly expenditure of farmers in the study area

\begin{tabular}{|l|l|l|l|l|}
\hline $\begin{array}{l}\text { Category and number of } \\
\text { farmers }\end{array}$ & Sum & Average & Minimum & Maximum \\
\hline $\begin{array}{l}\text { Small farmers } \\
1-12 \text { acres (cases325) }\end{array}$ & $61,71,425$ & 18,989 & 18,800 & 21,700 \\
\hline $\begin{array}{l}\text { Medium farmers } \\
13-25 \text { acres(cases 42) }\end{array}$ & $8,24,418$ & 19,629 & 18800 & 21,700 \\
\hline $\begin{array}{l}\text { Large farmers 26-50 and } \\
\text { above (cases 38) }\end{array}$ & $8,52,606$ & 22,437 & 19,200 & 27,700 \\
\hline
\end{tabular}


Table 7. Poverty line based on survey data and cost of basic needs (CBN) approach in study area used official poverty liners.3030 for each family member

\begin{tabular}{|l|l|l|l|l|l|l|l|l|}
\hline $\begin{array}{l}\text { Category of } \\
\text { farmers }\end{array}$ & Crop & $\begin{array}{l}\text { No of } \\
\text { farmers }\end{array}$ & $\begin{array}{l}\text { Average } \\
\text { size of farm } \\
\text { (in acres) }\end{array}$ & $\begin{array}{l}\text { Average } \\
\text { income per } \\
\text { acre (in Rs) }\end{array}$ & $\begin{array}{l}\text { Total } \\
\text { income (in } \\
\text { Rs) }\end{array}$ & $\begin{array}{l}\text { Average } \\
\text { net income } \\
\text { (in Rs) p.m } \\
\text { col 6/6* }\end{array}$ & $\begin{array}{l}\text { Average } \\
\text { monthly } \\
\text { expenditure (in } \\
\text { Rs) p.m }\end{array}$ & $\begin{array}{l}\text { Surplus } \\
\text { or deficit } \\
\text { (in Rs) }\end{array}$ \\
\hline 1 & 2 & 3 & 4 & 5 & 6 & 7 & 8 & 9 \\
\hline $\begin{array}{l}\text { Small farmers } \\
1-12 \text { acres }\end{array}$ & Wheat & 325 & 4.0 & 26,158 & 104,632 & 17,439 & 18,989 & -1550 \\
\cline { 2 - 9 } & Cotton & 325 & 4.0 & 53,921 & 215,684 & 35,947 & 18,989 & 16,958 \\
\hline $\begin{array}{l}\text { Medium } \\
\text { farmers } \\
13-25 \text { acres }\end{array}$ & Wheat & 42 & 16 & 26,682 & 426,912 & 71,152 & 19,629 & 51,523 \\
\cline { 2 - 9 } & Cotton & 42 & 15 & 55,160 & 827,400 & 137,900 & 19,629 & 118,271 \\
\hline $\begin{array}{l}\text { Large farmers } \\
26-50 \quad \text { and } \\
\text { above acres }\end{array}$ & Wheat & 38 & 32 & 28,118 & 899,776 & 149,963 & 22,437 & 127,526 \\
\cline { 2 - 9 } & Cotton & 38 & 30 & 62,445 & $1,873,350$ & 312,225 & 22,437 & 289,788 \\
\hline
\end{tabular}

Source: Study Survey 2017-18

The data given in the Table 5 describes income and cost per acre of 325 farmers, they had average size of farm 4 acres. The market rate was Rs.1245/- per maund, the minimum and maximum rates have also been mentioned in Table 5. They got net income of Rs.26,158/per acre after deduction of total cost from total income.The average, minimum and maximum production per acre are given in Table 5 . The total income of each farmer was Rs.104,632/this amount was divided by six months, hence they received monthly average net income of Rs.17,439/- from wheat production.

Table 5 also denotes medium farmers' had average yield per acre of wheat crop from 16 acres. The market rate was Rs.1268 per maunds, the minimum and maximum rate have also been mentioned in total income minus total cost, they got net income of Rs.26,682/- per acre. The average production remained 41.3 maunds per acre and the minimum 36 and maximum 45 maund per acre were also recorded. The total income of each farmer was Rs.426,912/- this amount was divided by six months, they received monthly average net income of Rs.71,152/- .

Table 5 describes the position of large farmers with regard to their income and cost. They had average size of farm land 32 acres. The average market rate was Rs.1294/- per maund, their average production remained 44.42 maunds per acre and the minimum 39 and maximum 45 maunds per acre were also recorded, the minimum and maximum rates are also mentioned. Thus large farmers got net income of Rs.28,118/- per acre after deduction of total cost from total income. Total income of each farmer was Rs.899,776/- this amount was divided by six months. Thus, they received average net income of Rs.149, 963/- per month.

The average monthly expenditures of all categories of farmers including, small, medium and large farmers remained Rs.18,989/-,
Rs.19,629/- and Rs.22,437/-, respectively. The minimum and maximum expenditure of all farmers have also been calculated (Table 6).

\section{Poverty status in the study area}

In Pakistan poverty was determined on estimation methodology which was based on the consumption data of the year 1999 during 2001 (PES, 2016). Later on Food Energy Intake (FEI) method was applied to measure poverty line as the same was adopted in many developing countries. The Planning Commission of Pakistan estimated official poverty line at Rs.637/- per person per month on minimum calories 2350 per day. It continued till 2007-08. This method was based on Food Poverty Line (FPL). It created difficulty in measuring poverty line and was scaled. The Planning Commission of Pakistan introduced new method of measuring poverty line it was known as Cost of Basic Needs (CBN) method in 2013-14. According to this method the expenditure Rs.3030 was calculated per person per month.

The above Table 7 indicates the average monthly income and expenditure of each group of farmers to determine poverty in the study area. In sample size 405 farmers are mentioned and are classified 325 small, 42 medium and 38 large groups. The average monthly income of small farmers was low as compared to other types of farmers. As per survey data, the average monthly income of small farmers was Rs.17,439/- and their average monthly expenditure was Rs.18,989/- which shows deficit of Rs 1550/- and as per CBN method Rs.3030/ per family member was fixed by Planning Commission of Pakistan, this amount is multiplied by family size which was six persons in the study area (Rs.3030x6 $=18,180$ $R s 18,989=-R s .809)$. This also shows deficit of Rs.809/-. It is observed that the small farmers were below the poverty line in winter season only (wheat crop). The average monthly income 
of medium and large farmers was at high side as compared to poverty line based on Cost of Basic Needs method. This study indicates that poverty was found in 325 small farmers out of 405 in the study area which stood 80 percent of total sample size. The Green Revolution policy introduced by the government had positive impact on agricultural productivity in Pakistan. Poverty in rural areas of Pakistan can be reduced further, if un-cultivated land be brought under cultivation through extension of irrigation facility.

\section{CONCLUSION}

The unfair distribution of water in the district Shaheed Benazirabad caused the shortage of water. Therefore, it is suggested that government should develop a machnism to fairly distribution of water significantly among small land owners in the study area. It has been observed that farmers do not get fair price in the market due to more production for example vegetables.Farmers do not store vegetables because of perishable commodity. Therefore, they sale their products at lower price. Therefore, Government of Pakistan should provide cold stores in the rural areas at lower cost and also enhance marketing skills among farmers.

\section{AUTHOR'S CONTRIBUTION}

A. A. Joyo: Selection of topic, research design, write-up, data collection, data compilation/ analysis

G. A. Jariko: Provided guidance in topic, overall supervision, expert views

Z. H. Channa: Support in data editing, compilation, contribution in data survey and helped in formation of tables

\section{REFERENCES}

Agricultural Statistics of Pakistan. 2010-11. published at Pakistan Bureau of Statistics, Government of Pakistan, Islamabad.

Ahmed, E. and S. Ludlow. 1989. Growth, Poverty and In: equality in Pakistan. Journal of Pakistan Development Review, Islamabad, 28: 4, Islamabad.

Ahmed, V. and A. Rashid. 1984. The Management of Pakistan's Economy. 194782, Oxford University Press, Karachi.

Amjad, R. and A. R. Kamal. 1997. Macro Economic Policies and their Impact on Poverty Alleviation in Pakistan, Pakistan Development Review, Vol. 36: 1, Islamabad.
Asghar, N. 2012. Government Spending Economic Growth and rural Poverty in Pakistan, Journal of Social Sciences, 32 (2): 469-483.

Asghar, N., Z. Hussain and H. U. Rehman. 2012. The impact of government spending on poverty reduction: Evidence from Pakistan 1972 to 2008. African Journal of Business Management, 6 (3): 845-853.

Bhutto, A. W. and A. A. Bazmi. 2007. Sustainable agriculture and eradication of rural poverty in Pakistan Abdul Waheed Bhutto and Aqeel Ahmed Bazmi, 31 (4): 253-262.

Dhrifi A. 2014. Agricultural Productivity and Poverty Alleviation: What Role for Technological Innovation. Journal of Economic and Social Studies, 4 (1): 139158.

Ercelawn, A. 1990. Absolute Poverty in Pakistan, Journal of Applied Economics, Research Centre, Karachi.

ESP, 2007. Economic Survey of Pakistan, 2006-2007, Islamabad.

ESP, 2009. Economic Survey of Pakistan, 2008-2009, Islamabad.

GoP, 2018. Agriculture Statistics of Pakistan 2015-16, Islamabad.

Idrees, M. 2017. Poverty in Pakistan: A RegionSpecific Analysis. The Lahore Journal of Economics, 22 (2): 139-163.

Imtiaz, A. 2014. Impact of Micro Finance on Poverty Reduction: A Case Study of District Faisalabad, Journal of Economics and Sustainable Development, 5 (9): 60-65.

Irshad, M. 2011. Post Harvest Management of Cereals in Pakistan, Government of Pakistan, HEC, Islamabad.

Malik, M. H. 1988. Some new evidence on the incidence of poverty in Pakistan. The Pakistan Development Review, 27 (4): 509515.

Murtaza, F. 2018. Readdressing Poverty Measurement Practice in Pakistan, Forman Journal of Economic Studies, 14: 175-197.

Naseem, S. M. 1981. Under-development, Poverty and in equality in Pakistan, Lahore, P. 250.

PES, 1967. Pakistan Economic Survey, 19661967, Islamabad.

PES, 1991. Pakistan Economic Survey, 199091, Islamabad.

PES, 2016. Pakistan Economic Survey, 201516, Islamabad.

PES, 2018. Pakistan Economic Survey 201718, Islamabad. 
PES, 2019. Pakistan Economic Survey 2018-19, Islamabad.

PES, 2020. Pakistan Economic Survey 201920, Islamabad.

Shirazi, N. S. and A. Khan. 2009. Role of Pakistan Poverty Alleviation Fund's Micro Credit in Poverty Alleviation: A Case of Pakistan. Journal of Pakistan Economic and Social Review, 47 (2): 215-228.
Yamane, T. 1967. Statistics, An Introductory Analysis, $2^{\text {nd }}$ Edition, New York, Harper and Row.

Zaidi, S.A. 2015. Issues in Pakistan's Economy, Karachi, third edition, published at Oxford University Press, Karachi.

(Received: June 18, 2019; Accepted: June 24, 2020) 